\title{
RELATIONSHIP BETWEEN THE RECURRENT LARYNGEAL NERVE AND THE INFERIOR THYROID ARTERY: A STUDY IN CORPSES
}

\author{
Bernardo Almeida Campos and Paulo Roberto Ferreira Henriques
}

RHCPFAP/3023

\begin{abstract}
CAMPOS BA et al. - Relationship between the recurrent laryngeal nerve and the inferior thyroid artery: a study in corpses.
Rev. Hosp. Clín. Fac. Med. S. Paulo 55(6):195-200, 2000.

The anatomical relationship between the recurrent laryngeal nerve (RLN) and the inferior thyroid artery (ITA) was studied in 76 embalmed corpses, 8 females and 68 males. In both sexes, the RLN lay more frequently between branches of the ITA.; it was found in this position in $47.3 \%$ of male corpses and $42.8 \%$ of female ones. On the right, RLN was found between branches of the ITA in $49.3 \%$ of the cases, anterior to it in $38.04 \%$, and posterior in $11.26 \%$. On the left, the RLN lay between branches of the ITA in $44.45 \%$, posterior to the ITA in $37.05 \%$, and anterior to it in $18.05 \%$ of the cases. In $62.68 \%$ of the cases, the relationship found on one side did not occur again on the opposite side. There was a significant difference $(\mathrm{p}<0.05)$ in the distribution of the 3 types of relationships between the RLN and the ITA, on the right and on the left. Racial variations could contribute to an explanation of the differences observed by authors of different countries in the relationship between the RLN and the ITA.
\end{abstract}

DESCRIPTORS: Anatomy. Recurrent laryngeal nerve. Inferior thyroid artery. Thyroid gland. Thyroidectomies.

Galen was the first to describe the recurrent laryngeal nerve (RLN) as a branch of a cranial nerve ${ }^{47}$.

The vagus nerve is formed by the end of the fifth week of embryonic development, and the branch that will originate the RLN becomes apparent by the end of the sixth week. This branch of the vagus nerve is associated with the sixth branchial arch of the embryonic pharynx, and it passes directly to the larynx. The embryo's system of aortic arches is associated with the pharynx. The vagus branch lies caudal to the aortic arches.

With the embryo's development, the neck elongates, and the larynx moves cranially while the aortic arch and associated vessels remain in the thorax, and, with them, the vagus branch. This branch, reaching the larynx directly when first developed, now forms the adult's characteristic recurrent loop ${ }^{16}$.

Therefore, the course of the RLN is determined by the pattern of development of the arteries with which it becomes related, and the variations of this pattern will determine variations in the anatomical disposition of this nerve ${ }^{16}$. Gray et al. ${ }^{16}$ had, at great length, described the embryonic development of the RLN as well as diverse possibilities of variations.

If the RLN develops without alterations, it will originate from the vagus

From the Laboratory of Surgical Technique of the Department of Surgery, Federal University of Minas Gerais. nerve and, on the right, surrounds the right subclavian artery, and on the left, surround the aortic arch. Before reaching its point of penetration in the larynx, the RLN ascends in the neck in the tracheoesophageal groove in most of the cases ${ }^{1,4,14,37}$. During this ascending passage, the RLN will cross the inferior thyroid artery (ITA).

Injury to the RLN is one of the most frequent and important causes of morbidity in thyroidectomies. The knowledge of its passage and of its anatomical relationships is essential in order to avoid such an injury. The objective of the present work was to study in corpses the relationship that the RLN establishes with the ITA, as well as to analyze some factors that can influence this relationship. 


\section{METHOD}

From July 1995 to July 1999, 76 embalmed corpses were dissected, 8 females and 68 males.

Access to the neck was achieved through a longitudinal incision in the median line associated with a curved transverse incision, creating 2 triangular flaps that were retracted laterally, allowing ample access to both sides of the neck. The recurrent laryngeal nerve (RLN) was dissected at its crossing point with the inferior thyroid artery (ITA).

There were 9 corpses with unilateral traumatic injuries to the RLN because of dissection, 5 injuries on the right and 4 on the left. The 9 injured sides were not included in the study. The 9 sides that had not been injured were added to the 134 sides of 67 corpses with no injury, totaling 143 complete sides, 71 on the right and 72 on the left.

The RLN was classified in accordance with its position, anterior, posterior, or between branches of the ITA.

The influence of the considered side (right or left) on the position of the RLN was analyzed. The influence of the sex of corpses on the position of the RLN was not analyzed due to the great difference in the available number of male and female specimens.

Statistical analysis of the results was conducted using the chi-square $\left(\mathrm{x}^{2}\right)$ test. The results were considered significant at $\mathrm{p}<0.05$.

\section{RESULTS}

The position of the recurrent laryngeal nerve (RLN) found in male and female corpses is presented in table 1 . In both sexes, the RLN lay more frequently between branches of the inferior thyroid artery (ITA), in $47.30 \%$ of male and $42.80 \%$ of female corpses. The available number of female corpses for dissection was small in relation to the number of male ones. Thus, the analysis of the difference in the distribution of the 3 types of relationships between the RLN and the ITA between the two sexes, was not performed. In one case in a male corpse, a right RLN originated a branch before crossing the ITA and involved one of the branches of this artery. Variations such as a non-recurrent laryngeal nerve or the absence of the ITA were not found in this study.

The relationship between the considered side (right and left) and the position of the RLN in relation to the ITA was analyzed (Table 2). On both sides, the RLN lay more frequently between branches of the ITA. This occurred in $49.3 \%$ of the cases on the right side and in $44.45 \%$ of the cases on the left side. There was a significant difference $(\mathrm{p}<0.05)$ in the distribution of the 3 types of relationships of the RLN with the ITA between the right and left sides.

The possible combinations between

Table 1 - Relationship between the recurrent laryngeal nerve (RLN) and the inferior thyroid artery (ITA) in male and female corpses.

\begin{tabular}{lrrrrr}
\hline Relationship & \multicolumn{2}{c}{ Males } & \multicolumn{2}{c}{ Females } \\
\cline { 2 - 7 } & $\mathbf{n}$ & $\boldsymbol{\%}$ & $\mathbf{N}$ & $\mathbf{\%}$ \\
\hline RLN anterior to the ITA & 36 & 27.90 & 4 & 28.60 \\
RLN posterior to the ITA & 31 & 24.03 & 4 & 28.60 \\
RLN between branches of the ITA & 61 & 47.30 & 6 & 42.80 \\
RLN branching off and involving one & 1 & 0.77 & - & - \\
branch of the ITA & & & & $\mathbf{1 4}$ & $\mathbf{1 0 0}$ \\
\hline Total & $\mathbf{1 2 9}$ & $\mathbf{1 0 0}$ & &
\end{tabular}

Table 2 - Relationship between the recurrent laryngeal nerve (RLN) and the inferior thyroid artery (ITA), considering the side of the neck.

\begin{tabular}{lcccccr}
\hline RLN position & \multicolumn{2}{c}{ Right side } & \multicolumn{2}{c}{ Left side } & \multicolumn{2}{c}{ Both sides } \\
\cline { 2 - 7 } & $\mathbf{n}$ & $\boldsymbol{\%}$ & $\mathbf{n}$ & $\boldsymbol{\%}$ & $\mathbf{n}$ & $\%$ \\
\hline Anterior to the ITA & 27 & 38.04 & 13 & 18.05 & 40 & 27.97 \\
Posterior to the ITA & 8 & 11.26 & 27 & 37.05 & 35 & 24.47 \\
Between branches of the ITA & 35 & 49.3 & 32 & 44.45 & 67 & 46.86 \\
RLN branching off and involving & 1 & 1.4 & - & - & 1 & 0.7 \\
$\mathbf{1}$ branch of the ITA & & & & & & \\
\hline Total & $\mathbf{7 1}$ & $\mathbf{1 0 0}$ & $\mathbf{7 2}$ & $\mathbf{1 0 0}$ & $\mathbf{1 4 3}$ & $\mathbf{1 0 0}$ \\
\hline
\end{tabular}

right and left sides found in this study were grouped (Table 3). In this study, we used only corpses in which both sides were complete, a total of 67 specimens. The most common combinations were: the RLN between branches of the ITA on the right and the left sides (23.88\%); the RLN between branches of the ITA on the right and posterior to the artery on the left side (19.4\%).

There was bilateral agreement in $37.32 \%$ of the cases $(n=25)$. In $62.68 \%$ $(n=42)$, the relationship found on one side did not occur again on the opposing side.

\section{DISCUSSION}

Some conditions can cause recurrent laryngeal nerve (RLN) palsy ${ }^{15,34,41,42}$. Surgical injuries produce 11 to $32 \%$ of these $^{31,42}$. Some procedures that may result in injury to the RLN are: thyroidectomies, parathyroidectomies, ex- 
Table 3 - Combinations of the recurrent laryngeal nerve (RLN) positions considering both sides in the same corpse.

\begin{tabular}{llrc}
\hline \multicolumn{1}{c}{ Position of the RLN } & n & \% \\
\hline \multicolumn{1}{c}{ Right side } & \multicolumn{1}{c}{ Left side } & 5 & 7.46 \\
\hline Anterior to the ITA & Anterior to the ITA & 4 & 5.97 \\
Posterior to the ITA & Posterior to the ITA & 16 & 23.88 \\
Between branches of the ITA & Between branches of the ITA & 11 & 16.42 \\
Anterior to the ITA & Between branches of the ITA & 9 & 13.43 \\
Anterior to the ITA & Posterior to the ITA & 1 & 1.5 \\
Posterior to the ITA & Between branches of the ITA & 3 & 4.47 \\
Posterior to the ITA & Anterior to the ITA & 4 & 5.97 \\
Between branches of the ITA & Anterior to the ITA & 13 & 19.4 \\
Between branches of the ITA & Posterior to the ITA & 1 & 1.5 \\
$\begin{array}{l}\text { The RLN branching off and } \\
\text { involving one branch of the ITA }\end{array}$ & Between branches of the ITA & & \\
\hline \multicolumn{1}{c}{ Total } & & $\mathbf{6 7}$ & $\mathbf{1 0 0}$ \\
\hline
\end{tabular}

ITA: inferior thyroid artery

cision of Zenker's diverticulum, esophagectomies, tracheoplasties, neck dissections, correction of a patent ductus arteriosum, mediastinoscopy, and others ${ }^{11,31,42}$.

Thyroidectomy is the surgery in which this injury occurs most frequently. According to Titche ${ }^{42}$, thyroidectomy accounts for $35.71 \%$ of surgical causes of injury to the RLN, and accounts for $3.73 \%$ of all causes. The incidence of injury to the RLN in thyroidectomies ranges from 0 to $12 \%$ 22,24,25,28,33,36,40. This injury occurs more frequently when a branch of the ITA is inadvertently sectioned. In an attempt to achieve hemostasis, the nerve is clipped and/or separated with the arterial branch ${ }^{24,25,32,36,37}$.

Although some authors ${ }^{30,33}$ defend the display of the RLN only in specific situations, most agree that the routine display of the RLN is essential for its protection $^{4,14,18,21,22,24,25,28,31,36,37,39,40}$. Lahey $^{24}$, performing the routine display of the RLN in 3000 cases, obtained a reduction in the incidence of injury from 1.5 to $0.3 \%$. The same author in a subsequent work, systematically visualized the nerve, in more than 3446 thyroidectomies with no injury ${ }^{25}$. However, excessive manipulation and dissection must be avoided so the nerve is brought under visual control without risk of compromising its vascularization. To this end, the ITA functions as a fixed reference point for the location of the r.l.n. ${ }^{22,25,33,36}$. The knowledge of the relationship between the RLN and the ITA is also important for the exteriorization of the thyroid lobe ${ }^{12,37}$.

Reed $^{32}$ described 28 different types of relationships between the RLN and the ITA, classifying them in 3 main types. Freschi ${ }^{14}$ considered 8 possible relationships between these two structures. Most authors, beyond the classic anatomy textbooks, recognize 3 types of relationships between the RLN and the ITA, as follows ${ }^{1-5,7,8,10,12,13,15,19,20,26,29,32,36,37,41,45}$ :

a) RLN anterior to ITA;

b) RLN posterior to ITA;

c) RLN between branches of ITA.

Simon $^{36}$, after the dissection of 86 nerves in 43 corpses, affirmed that the usual relationship is the one in which the RLN establishes by passing poste- riorly the ITA. The anterior orientation of the nerve in relation to the artery was occasional, while its position between the arterial branches was a rare finding. Lahey ${ }^{24}$, based on surgical findings, had a similar opinion.

Analyzing 17 studies which reported this relationship, when considering the both sides as a set, 16 showed that the RLN is more frequently located posterior to the ITA, between $39.08 \%$ to $75.58 \%$ of the time 1-5, $, 7,12,13,19,20,26,32,36,37,39,45$.

Considering right and left sides separately, differences appear. On the left, in 15 analyzed works, 14 showed the predominance of the posterior position of the nerve in relation to the artery ${ }^{1-5,8,12,19,20,26,32,36,37,39,45}$.

On the right, the variation is larger. Analyzing the same 15 works, 8 showed that the RLN passes more frequently between the branches of the ITA. In 5, the RLN passed posterior to the ITA in most cases, and in only 2 studies was it placed anterior to the artery with higher frequency ${ }^{1-5,8,12,19}$ 20,26,32,36,37,39,45

Flament et al. ${ }^{12}$ in France, found the RLN between the branches of the ITA in most cases, both on the right and on the left side. In the sample presented here, we found similar results to those of the French author: the RLN lay between the branches of the ITA in $46.86 \%$, anterior to the branches in $27.97 \%$, and posterior to the branches in $24.47 \%$ of the cases when considering both sides.

On the left side, the RLN lay between branches of the ITA in $44.45 \%$, posterior in $37.05 \%$, and anterior to the arterial branches in $18.05 \%$ of the cases.

On the right, the RLN lay between branches of the ITA in $49.3 \%$, anterior in $38.04 \%$, and posterior in $11.26 \%$ of the cases. In 1 case, on the right, the RLN branched off before crossing the ITA, and it surrounded one of its branches. In the works in which this variation was found, it occurred from 
$1 \%$ to $5.4 \%$ of the cases, when considering both sides ${ }^{3,32}$.

Reed $^{32}$ in the U.S.A., found different relationships on the two sides in $17 \%$ of the cases. Hirata ${ }^{19}$ in Japan, found the same relationship on the two sides in $40 \%$ of male corpses and in $28.6 \%$ of female ones. Sturniolo ${ }^{39}$ in Italy, found the same relationship on both the sides in $51.2 \%$ of the cases. The same author found a different relationship between the two sides $48.8 \%$ of the time. In the sample presented here, only in $37.32 \%$ of the cases did the orientation found on one side occur again in the opposing side.

The most frequent combinations in our study were: the RLN between the branches of the ITA on the right and on the left ( $23.88 \%$ of the cases); and the RLN between the branches of the ITA on the right and posterior on the left $(19.4 \%$ of the cases).

Hirata $^{19}$ in Japan, found a significant difference in the percentile distribution of the 3 types of relationships of the RLN with the ITA between the two sides. He did not find a significant difference between males and females. This author found that the difference between the two sides could be attributed to the difference in the anatomical course of the RLN on the right and on the left. In the present sample, the results of this analysis are similar to the ones of the Japanese author. The difference between the two sides (right and left) of the orientation of the RLN in relationship to the ITA was significant. Among us, Costa et al. ${ }^{8}$ have not found a significant difference in the relationship between the RLN and the ITA between the two sides.

The factors that determine these observed differences in the anatomical variations of the RLN are still not established. Pereira ${ }^{30}$ and Lages $^{23}$ in independent works, when reporting cases of non-recurrent laryngeal nerve, in vivo and in a corpse respectively, emphasized that the racial factor should receive greater attention. Both findings had occurred in crossbred female individuals, according to the authors. Steinberg et al. ${ }^{38}$ in South Africa, dissected 180 nerves in 90 corpses that were not embalmed. Among the corpses, $80 \%$ were of black race, $12 \%$ were of Caucasian race, and $8 \%$ were of Asian race. The authors found, regarding its relationship with the ITA, the RLN had divided into 2 main branches in $68 \%$ of the cases. In a small percentage, one of these branches was also subdivided. In $75 \%$ of the dissections, the branches of the RLN interdigitated with the branches of the ITA. There was no such thing as a constant relationship between these two structures.

It would be interesting to analyze the influence of racial differences on the relationship between the RLN and the ITA, based on works of different nationalities ${ }^{1-5,7,8,12,13,19,20,26,32,36,38,45}$ (Table 4), that were done primarily in populations with well-defined racial features. In those studies, which were carried out on embalmed corpses, these racial features are frequently lost. This fact, as well as the great racial miscegenation found among us, were the reasons why this analysis was not carried out in the present sample. But even those works where data were obtained from corpses during autopsy, or in surgical cases, there is no information permitting a racial characterization of the samples and a rigorous evaluation of the data from this standpoint.

The idea that the RLN is more frequently posterior to the ITA, and moreover, expecting this relationship to repeat on both sides, gives the surgeon a false sense of security. If the nerve lies anterior to, or between the branches of the ITA, the withdrawal of the thyroid gland from its stream bed results in the withdrawal of the nerve, with injury being more likely than when the nerve is posterior to the i.t.a. ${ }^{12,37}$. Understanding of this concept is essential, especially when the surgeon must perform a total thyroidectomy. In these cases, some authors prefer to ligate the ITA and its

Table 4 - Relationship between the recurrent laryngeal nerve (RLN) and the inferior thyroid artery (ITA). Results of other authors considering right and left sides together.

\begin{tabular}{|c|c|c|c|c|c|c|}
\hline Author & Year & Country & $\begin{array}{c}\text { Number of } \\
\text { visualized } \\
\text { nerves }\end{array}$ & $\begin{array}{c}\text { RLN } \\
\text { anterior } \\
\text { to the } \\
\text { ITA }(\%)\end{array}$ & $\begin{array}{c}\text { RLN } \\
\text { posterior } \\
\text { to the } \\
\text { ITA }(\%)\end{array}$ & $\begin{array}{c}\text { RLN } \\
\text { between } \\
\text { branches } \\
\text { of the } \\
\text { ITA }(\%)\end{array}$ \\
\hline Fowler \& Hanson ${ }^{13}$ & 1929 & U.S.A. & 400 & 26 & 65.5 & 8.5 \\
\hline Berlin $^{4}$ & 1935 & U.S.A. & 140 & 32.14 & 53.57 & 14.29 \\
\hline Reed $^{32}$ & 1943 & U.S.A. & 506 & 18.6 & 39.1 & 36.5 \\
\hline Bachhuber $^{3}$ & 1943 & U.S.A. & 200 & 14.5 & 44 & 40.5 \\
\hline Simon $^{36}$ & 1943 & U.S.A. & 86 & 17.44 & $75.58 *$ & $6.98 *$ \\
\hline Armstrong \& Hinton ${ }^{2}$ & 1951 & U.S.A. & 100 & 34 & 43 & 23 \\
\hline Bowden $^{5}$ & 1955 & U.K. & 58 & 18.97 & 41.38 & 34.48 \\
\hline Wade $^{45}$ & 1955 & U.K. & 200 & $10.5 *$ & 47.5 & 34.5 \\
\hline Hunt et al. ${ }^{20}$ & 1968 & Australia & 151 & 29 & 57 & 9 \\
\hline Skandalakis et al. ${ }^{37}$ & 1976 & U.S.A. & 204 & 20.6 & 41.6 & 37.3 \\
\hline Chang-Chien $^{7}$ & 1980 & Taiwan & 100 & 24 & 56 & 20 \\
\hline Flament et al. ${ }^{12}$ & 1983 & France & • & 19.45 & 30.2 & $50.35 *$ \\
\hline Al-Salihi \& Dabbagh ${ }^{1}$ & 1989 & Iraq & 212 & 23.11 & 53.78 & 23.11 \\
\hline Hirata $^{19}$ & 1992 & Japan & 784 & 18.65 & 46.25 & 35.1 \\
\hline Lekacos et al. ${ }^{26}$ & 1992 & Greece & 191 & 16 & 51 & 33 \\
\hline Costa et al. ${ }^{8}$ & 1997 & Brazil & 98 & $37.76^{*}$ & 39.08 & 22.44 \\
\hline Sturniolo et al. ${ }^{39}$ & 1999 & Italy & 280 & 31.1 & 43.2 & 25.7 \\
\hline Campos \& Henriques & 2000 & Brazil & 143 & 27.97 & $24.47 *$ & 46.86 \\
\hline
\end{tabular}

*minimum and maximum percentage value for each position.

- based on dissection of 100 corpses and on 600 surgical interventions upon thyroid gland. 
branches next to glandular parenchyma, without approaching its trunk, in order not to include the RLN and at the same time, not to compromise the irrigation of the parathyroids ${ }^{6,40}$.

Therefore, the identification and visual control of the RLN and the ITA, as well as the determination of their anatomical relationships, are essential principles for diminishing morbidity related to thyroidectomies.

\section{CONCLUSIONS}

On the right side in most cases, the recurrent laryngeal nerve (RLN) was found between the branches of the inferior thyroid artery (ITA), followed by, in decreasing order of frequency, positions anterior and posterior to the artery.

On the left, the RLN was also placed more frequently between the branches of the ITA, followed by, in decreasing order of frequency, positions posterior and anterior to the ITA.

There was a statistically significant difference $(\mathrm{p}<0.05)$ in the distribution of these 3 types of relationships between right and left sides.

In $62.68 \%$ of the cases, the relationship found on one side did not occur again on the opposing side.

Racial variations could contribute to the explanation of the differences observed in the relationship between the RLN and the ITA.

\section{ACKNOWLEDGEMENTS}

We would like to thank Professors Ernesto Lentz de Carvalho Monteiro from the Department of Surgery, Ezequiel Rubinstein from the Department of Morfology and Geraldo Cunha Coury from the Department of Preventive and Social Medicine, of the Federal University of Minas Gerais, for their inestimable suggestions.
CAMPOS BA e col. - Relação entre o nervo laríngeo recorrente e a artéria tireóidea inferior: um estudo em cadáveres. Rev. Hosp. Clín. Fac. Med. S Paulo 55(6):195-200, 2000.

A relação anatômica entre o nervo laríngeo recorrente (NLR) e a artéria tireóide inferior (ATI) foi estudada em 76 cadáveres formolizados, sendo oito do sexo feminino e 68 do sexo masculino. Em ambos os sexos, o NLR se colocou mais freqüentemente entre ramos da ATI, sendo encontrado nessa posição em $47,3 \%$ das vezes no sexo masculino e $42,8 \%$ das vezes no sexo feminino. À direita, o NLR foi encontrado entre ramos da ATI em 49,3\% dos casos, anteriormente em $38,04 \%$ e posteriormente em $11,26 \%$. À esquerda, o NLR se colocou entre ramos da ATI em 44,45\% das vezes, posteriormente em $37,05 \%$ e anteriormente em $18,05 \%$. Em 62,68\% das vezes a relação encontrada em um lado não se repetiu no lado oposto, no mesmo cadáver. Houve diferença significativa $(\mathrm{p}<0,05)$ na distribuição dos três tipos de relação entre o NLR e a ATI, entre os lados direito e esquerdo. Variações raciais poderiam contribuir para explicar as diferenças observadas por autores de diferentes países na relação entre o NLR e a ATI.

DESCRITORES: Nervo laríngeo recorrente. Artéria tireóide inferior. Glândula tireóidea. Tireoidectomias.

\section{REFERENCES}

1. AL-SALIHI AR \& DABBAGH AW - Anatomy of the recurrent laryngeal nerve in normal Iraqis. Acta Anat 1989; 135:245-247.

2. ARMSTRONG WG \& HINTON JW - Multiple divisions of the recurrent laryngeal nerve - an anatomic study. Arch Surg 1951; 62:532-539.

3. BACHHUBER CA - Complications of thyroid surgery - anatomy of the recurrent laryngeal nerve, middle thyroid vein and inferior thyroid artery. Am J Surg 1943; 60:96-100.

4. BERLIN DD - The recurrent laryngeal nerves in total ablation of the normal thyroid gland - an anatomical and surgical study. Surg Gynecol Obstet 1935; 60:19-26.

5. BOWDEN REM - The surgical anatomy of the recurrent laryngeal nerve. Brit J Surg 1955; 43:153-163.
6. CAGNOL G, SANTINI J \& DEMARD F - Anatomy of the recurrent nerve - descriptive anatomy, trajectory and relationships, variations. Acta Otorhinolaryngol Belg 1987; 41(5):821-827.

7. CHANG-CHIEN Y - Surgical anatomy and vulnerability of the recurrent laryngeal nerve. Int Surg 1980; 65(1): 23-30.

8. COSTA MAAG, CAVALCANTI JS, OLIVEIRA EL et al. Contribuição ao estudo das relações da artéria tireóidea inferior com o nervo laríngeo recorrente e o tronco simpático. Rev Bras Cirurgia 1997; 87(1):3-7.

9. CRILE GW - The prevention of abductor paralysis in thyroidectomy. Surg Gynecol Obstet 1929; 49:538-539.

10. DÂNGELO JG \& FATTINI CA - Anatomia humana sistêmica e segmentar. $2^{\mathrm{a}}$ ed. Rio de Janeiro, Atheneu, 1988. 
11.EECKHAUT JVD - The recurrent laryngeal nerve. Acta Otorhinolaryngol Belg 1983; 37(3): 388-397.

12. FLAMENT JB, DELATTRE JF \& PALOT JP - Les piéges anatomiques de la dissection du nerf récurrent. J Chir (Paris) 1983; 120(5): 329-333.

13. FOWLER CH \& HANSON WA - Surgical anatomy of the thyroid gland with special reference to the relations of the recurrent laryngeal nerve. Surg Gynecol Obstet 1929; 49: 59-65.

14.FRESCHI G, MASI C, GRAZIANI MP et al. - Considerazioni anatomo-chirurgiche sul nervo laringeo ricorrente in corso di tiroidectomia. Minerva Chir 1994; 49: 943-947.

15. GARDNER E, GRAY DJ \& O'RAHILLY R - Anatomia: estudo regional do corpo humano. $3^{\text {a. }}$ ed. Rio de Janeiro, Guanabara Koogan, 1971.

16. GRAY SW, SKANDALAKIS JE \& AKIN JT - Embryological considerations of thyroid surgery: developmental anatomy of the thyroid, parathyroids and the recurrent laryngeal nerve. Am Surg 1976; 42: 621-628.

17. HENRY JF, AUDIFFRET J \& PLAN M - Le nerf laryngé inférieur non récurrent - a propos de 19 observations dont 2 du côté gauche. J Chir 1985; 122 (6-7):391-397.

18. HENRY JF, AUDIFFRET J, DENIZOT A et al. - The nonrecurrent inferior laryngeal nerve: review of 33 cases, including two on the left side. Surgery1988; 104(6): 977-984.

19. HIRATA K - Relationship between the recurrent laryngeal nerve and the inferior thyroid artery in japanese. Kaibogaku Zasshi.1992; 67(5): 634-641

20. HUNT PS, POOLE M \& REEVE TS - A reappraisal of the surgical anatomy of the thyroid and parathyroid glands. Brit J Surg 1968; 55(1):63-66.

21. KAHKY MP \& WEBER RS - Complications of surgery of the thyroid and parathyroid glands. Surg Clin North Am 1993; 73(2): 307321

22. KARLAN MS, CATZ B, DUNKELMAN D et al. - A safe technique for thyroidectomy with complete nerve dissection and parathyroid preservation. Head Neck Surgery 1984; 6: 1014-1019.

23. LAGES L - Nervo laríngeo inferior não recurrente e artéria subclávia direita retro-esofagiana (importância desta anomalia do ponto de vista clínico-cirúrgico). Arq Fac Nac Med 1946; 1:29-57.

24. LAHEY FH \& HOOVER WB - Injuries to the recurrent laryngeal nerve in thyroid operations. Ann Surg 1938; 108: 545-562.

25. LAHEY FH - Routine dissection and demonstration recurrent laryngeal nerve in subtotal thyroidectomy. Surg Gynecol Obstet 1938; 66: 775-777.

26. LEKACOS NL, TZARDIS PJ, SFIKAKIS PG et al. - Course of the recurrent laryngeal nerve relative to the inferior thyroid artery and the suspensory ligament of Berry. Int Surg 1992;77:287-288.

27. MANSBERGER AR \& WEI JP - Surgical embryology and anatomy of the thyroid and parathyroid glands. Surg Clin North Am 1993; 73(4): 727-746.

28. MAX MH, SCHERM M \& BLAND KI - Early and late complications after thyroid operations. South Med J 1983; 76(8): 977-980.
29. MOREAU S et al. - The recurrent laryngeal nerve : related vascular anatomy. Laryngoscope 1998;108:1351-1353.

30. PEREIRA AF - Laríngeo inferior não recurrente. Rev Bras de Cirurgia 1951; 22: 347-354

31. PREMACHANDRA DJ, RADCLIFFE GJ \& STEARNS MP Intraoperative identification of the recurrent laryngeal nerve and demonstration of its function. Laryngoscope 1990; 100:94-96.

32. REED AF - The relations of the inferior laryngeal nerve to the inferior thyroid artery. Anatom Record 1943; 85: 17-23.

33. RIDDELL VH - Injury to recurrent laryngeal nerves during thyroidectomy - a comparison between the results of identification and non-identification in 1022 nerves exposed to risk. Lancet 1956; 2:638-641.

34. ROWE - JONES JM, LEIGHTON SEJ \& ROSSWICK RP - Benign thyroid disease and vocal cord palsy. Ann R Coll Surg Eng 1993 75(4): 241-244

35. SANDERS I, WU BL, MU L et al. - The innervation of the human larynx. Arch Otolaryngol Head Neck Surg 1993; 119(9): 934-939.

36. SIMON MM - Recurrent laryngeal nerve in thyroid surgery - triangle for its recognition and protection. Amer J Surg 1943; 60(2): 212 220 .

37. SKANDALAKIS JE, DROULIAS C, HARLAFTIS $\mathrm{N}$ et al. - The recurrent laryngeal nerve. Am Surg 1976; 42 : 629-634.

38. STEINBERG JL, KHANE GJ, FERNANDES CMC et al. - Anatomy of the recurrent laryngeal nerve: a redescription. Laryngol Otol 1986; 100 : 919-927.

39. STURNIOLO G, D ALIA C, TONANTE A et al. - The recurrent laryngeal nerve related to thyroid surgery. Amer J Surg 1999 177(6):485-488.

40. TCHEKMEDYIAN V, AGUIRRE C, RICCIARDI N et al. - Técnica quirúrgica en la tiroidectomía para reducir la agresión recurrencial. Cir Uruguay 1981; 51(2): 141-143.

41. TESTUT L \& JACOB O - Tratado de anatomia topográfica con aplicaciones médicoquirúrgicas. $8^{\mathrm{a}}$ ed. Barcelona, Salvat Ed. 1950. [Tomo primero].

42. TITCHE LL - Causes of recurrent laryngeal nerve paralysis. Arch Otolaryngol 1976; $102: 259-261$.

43. TZINAS S, DROULIAS C, HARLAFTIS N et al. - Vascular pattern of the thyroid gland. Am Surg 1976; 42: 639-644.

44. VUILLARD P, BOUCHET A, GOUILLAT C et al. - Le nerf laryngé inférieur non récurrent - a propos de quinze cas opératoires. Bull Assoc Anat (Nancy) 1978; 62(179) : 497-505.

45. WADE JSH - Vulnerability of the recurrent laryngeal nerves at thyroidectomy. Brit J Surg 1955; 43: 164-180.

46. WAFAE N, VIEIRA MC \& VOROBIEFF A - The recurrent laryngeal nerve in relation to the inferior constrictor muscle of the pharynx. Laryngoscope 1991; 101: 1091-1093.

47. WALSH J - Galen's discovery. Ann Med History 1926; 8:176-184. apud SIMON, $\mathrm{M} \mathrm{M}^{36}$

Received for publication on the 11/05/00 